Western University Scholarship@Western

1995

\title{
A Search Interpretation of Male-Female Wage Differentials
}

\author{
Audra J. Bowlus \\ University of Western Ontario, abowlus@uwo.ca
}

Follow this and additional works at: https://ir.lib.uwo.ca/economicsresrpt

Part of the Economics Commons

Citation of this paper:

Bowlus, Audra J.. "A Search Interpretation of Male-Female Wage Differentials." Department of Economics Research Reports, 9504. London, ON: Department of Economics, University of Western Ontario (1995). 


\title{
RESEARCH REPORT 9504
}

\author{
A Search Interpretation \\ of Male-Female Wage Differentials \\ by
}

Audra J. Bowlus

March 1995

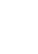 \\ N6A $5 \mathrm{C2}$
}

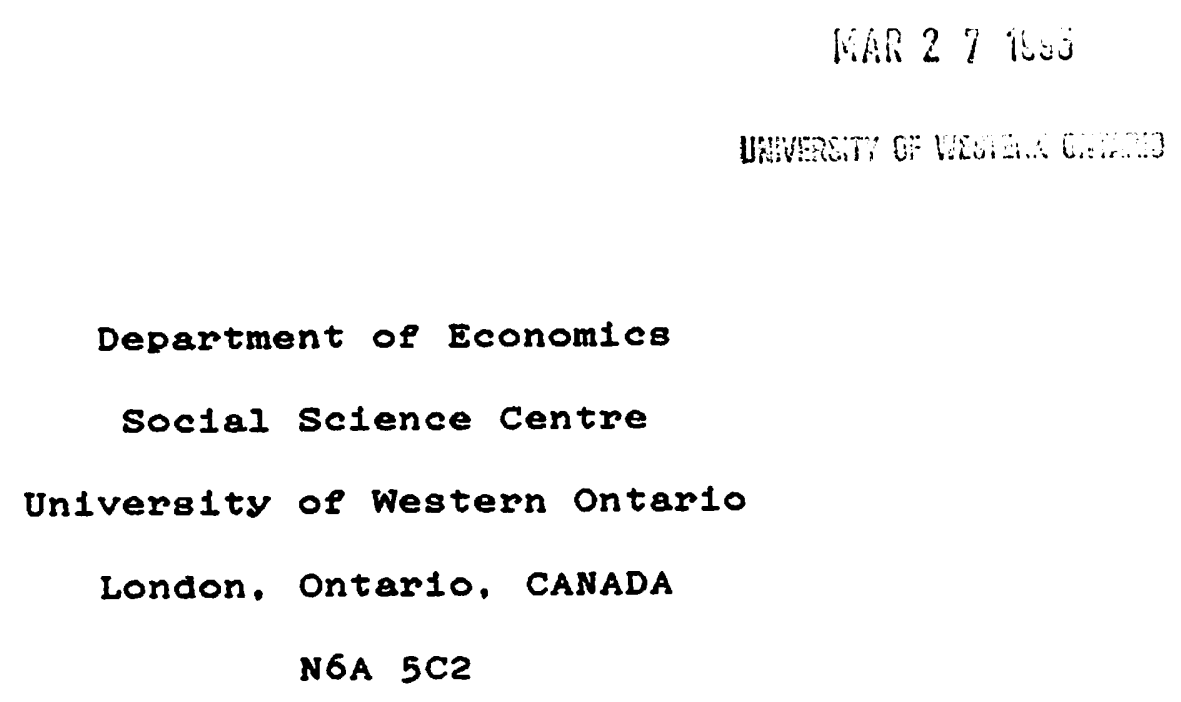

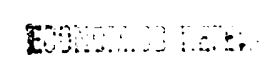

$\operatorname{likn} 27 \mathrm{iuj}$

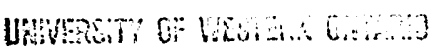




\title{
A Search Interpretation of Male-Female Wage Differentials
}

\author{
Audra J. Bowlus \\ March 1995
}

\begin{abstract}
A general equilibrium search framework is used in this paper to examine the role of differences in behavioural patterns of labour force participation across the sexes in determining male-female wage differentials. A 3-state model of the labour market is put forth and estimated with data on wages and durations from the NLSY. The results indicate that men and women exhibit significantly different behavioural patterns, as well as face varying labour market conditions with respect to job finding and job loss rates. In certain cases, particularly for college graduates, the male-female wage differential can be substantially reduced by increasing the competition for female workers (raising(lowering) their job finding(loss) rates) or by reducing the tendency for females to exit for personal reasons.
\end{abstract}

* Department of Economics, University of Western Ontario, London, Ontario, Canada N6A 5C2. I have benefitted from helpful comments and suggestions by George Neumann, Joel Horowitz, and seminar participants at University of Western Ontario and McMaster University. All remaining errors are my own. 


\section{INTRODUCTION}

It is a commonly held view that differences in behavioural patterns across the sexes contribute to male-female wage differentials. This view is often framed in a human capital context where training investments made by firms and workers and, therefore, wages are influenced by expected labour force participation patterns (Mincer and Polachek (1974), Sandell and Shapiro (1980), Mincer and Ofek (1982)). ${ }^{1}$ Researchers have also looked at the effect of behavioural differences within other frameworks. Ragan and Smith (1981) cite hiring and firing costs as a reason behind why firms may discount wages of high turnover groups. Several studies have investigated the effect of differences in turnover on wages in search and, now more recently, matching frameworks. ${ }^{2}$ Most of these studies treat all separations as the same or at most distinguish between quits and layoffs. Sicherman (1993), an exception, shows that this hides some of the largest differences across the sexes. Using detailed data from a large firm, he finds that disaggregated quit patterns differ substantially across the sexes, in particular, this is true by reason and state to which exit is made. Women exit employment more often, are more likely to exit for personal reasons, and upon leaving employment are more likely to leave the labour force.

This paper extends this literature in three ways. First, I show that in a general equilibrium search framework it is important to distinguish between types of quit behaviour as each affects the equilibrium wage distribution differently. Second, I put forth and estimate a 3-state search model which allows for these quit behaviours. Estimation results show the hypothesis of men and women exhibiting common behavioural patterns is rejected by the data. Third, I estimate the model separately for men and women to determine how important these turnover differences are in explaining male-female wage differentials.

\footnotetext{
${ }^{1}$ The most recent and careful study of experience differences across the sexes, Light and Ureta (1995), finds the timing of experience matters as well as total experience. The estimated returns to experience in their full work history model are significantly higher than those found with standard experience measures and accounting for differences in the timing of experience explains $12 \%$ of the raw gender wage gap.

${ }^{2}$ The studies on quit behaviour include Viscusi (1980), Barnes and Jones (1974), Light and Ureta (1990,1992), Blau and Kahn (1981), Meitzen (1986), Donahue (1988) and Sicherman (1993). The more recent work on matching includes Hersch and Reagan $(1990,1994)$ and Royalty (1993a,1993b).
} 
To do this I develop a model which allows for three types of job separation behaviour: exits into unemployment (job loss), exits out of the labour force (personal), and quits to take a better job. The model is based on Mortensen's (1990) 2-state model of search both on and off the job. To better capture exit patterns of females and their extended time out of the labour force, I add a third state consisting of non-employment without search.

The importance of distinguishing between different types of quit behaviour stems from the fact that each influences the workers' and firms' decision problems (and, therefore, the wage distribution) differently. In the model workers solve a standard search utility maximization problem and adopt a reservation wage strategy. Workers set reservation wages by equating the value of being unemployed to the value of being employed at the reservation wage. The workers' reservation wage is influenced by exit rates because they enter into the valuation of employment and unemployment. Quits due to outside job offers do not have the same effect as exits due to job loss or personal reasons. The former make employment more valuable while the latter reduce the value of being employed. Thus two groups facing the same labour market conditions - job offer arrival rates and job loss rates - but with different tendencies to exit for personal reasons will have different reservation wage strategies.

Firms take the workers' reservation wage strategies as given and set wages to maximize profits. Because offers do not arrive immediately and instantaneously as in a competitive framework, firms are able to exert monopsony power over workers - pay a wage lower than marginal product. The firms' profit function is composed of this monopsony rent per worker and the labour supply function. Like the workers' reservation wage strategy the labour supply function is also affected differently by exits due to outside offers and those due to job loss or personal concerns. The latter are separations which lower the labour supply to all firms, while the former influence how fast labour supply increases with the wage. Paying a higher wage attracts workers with lower wages and retains them longer as workers with high wages are less likely to receive acceptable outside offers. Thus a balancing of monopsony rents and 
labour supply leads some firms to specialize in low wage, high turnover strategies while others operate with high wages and low turnover. The Nash equilibrium in this model, which brings together the strategies of firms and workers, requires that expected profits are equal. The equilibrium wage offer distribution, which traces out this equal profit constraint, is therefore affected by behavioural patterns.

With data from the National Longitudinal Survey of Youth (NLSY) I explore the effect behavioural patterns have on the wages of individuals just starting their careers by examining wages on first full-time jobs after formal education. The data show significant male-female wage differentials for first jobs. In addition, women are much more likely than men to leave jobs for personal reasons. And doing so results in non-employment spells that are much longer on average than those due to job-related reasons. Non-employment spells for men on average are the same length regardless of the reason. I also find that on average men have shorter non-employment durations than women. Under the search framework all of these relationships imply a lower mean wage for females. The question is: how well does the search model explain the above patterns, and to what extent do they contribute to the observed wage differentials? To answer this question I depart from common wage regression frameworks and estimate the model directly using the approach of Bowlus, Kiefer and Neumann (1995b).

I estimate the model for two education groups: high school graduates and college graduates. For both groups I find the assumption of men and women exhibiting the same behavioural patterns is rejected by the data. The additional non-employment state is important for both female groups, but not for either group of males. I also find that females have a lower reservation wage than males in both education groups. The model explains this finding through higher job dissolution and personal exit rates, as well as lower job finding rates, for females. Thus differences in labour market conditions, as well as behavioural patterns concerning labour force participation, are important. However, the model cannot explain the entire differential using these patterns. The residual portion is, here as in other models, attributed to productivity differences across the sexes. 
To assess the contribution of these differences across the sexes to the male-female wage differentials, I compute reservation wages and expected earnings for females assuming (a) that females face the same patterns in the labour market as males and (b) that females face a change in their behavioural pattern such that they no longer exit for personal reasons. Comparing results under (a) and (b) to the actual data I find in certain cases that the wage differential can be substantially reduced. This is particularly true for college graduates. Thus suggesting programs which help women stay in the labour force or increase their job opportunities may be helpful in reducing the male-female wage differential.

The rest of the paper is organized as follows. Section II contains a description of the model. The likelihood function and estimation procedure are described in Section III. A description of the data is given in Section IV and results of the estimation are presented in Section V. Conclusions are made in Section VI.

\section{MODEL}

The choice of a 3-state model over a 2-state model is driven by the evidence, primarily for females, that non-participation and unemployment are distinct states. That is, the exit rate out of nonparticipation is not the same as that out of unemployment. Evidence from Burdett et al. (1984) shows that for women the tendency to go into non-employment, particularly non-participation, is higher than for men and that durations are longer. Swaim and Podgursky (1994) find that labour force withdrawal is an important factor in determining post-displacement jobless spells for women. Flinn and Heckman (1983) find that unemployment and non-participation are distinct states for a sample of young men from the NLS Young Men data set, while in a study using the NLSY Gönül (1992) finds they are distinct states for only young women and not for young men.

The model is composed of three states: (1) employment, where on-the-job search occurs; (2) unemployment, where search also occurs; and (3) non-participation, where search does not occur. It is 
assumed one must be searching in order to receive job offers and become employed. Thus the following transitions are possible: unemployment to employment, job to job, employment to unemployment, employment to non-participation, unemployment to non-participation, and non-participation to unemployment. There is no direct transition from non-participation to employment. Five parameters govern the above transitions: the arrival rate of offers while unemployed, $\lambda_{0}$; the arrival rate of offers while employed, $\lambda_{1}$; the job destruction rate, $\delta$, which causes transitions to unemployment; the arrival rate of 'personal' concerns, $\eta_{1}$, which forces transitions to non-participation; and $\eta_{2}$ the rate at which those concerns are resolved, which forces transitions to unemployment. Personal concerns can arise at anytime while a worker is employed or unemployed. Their arrival rate, as well as the waiting time until these concerns are alleviated, is independent of the labour market state. Obviously there are many kinds of events that fit this description -- illness, the birth of a child, the loss of a relative, etc. If a person is searching for employment, the arrival of personal concerns simply detours the individual into a holding pattern, after which she emerges to search further. If the personal concern arrives during an employment spell, I assume that it results in an exit to non-participation and that the person's job is not retained.

In the model workers, taking the wage offer distribution of the firms as given, solve the standard search utility maximization problem and adopt a reservation wage strategy. Following Mortensen and Neumann (1988) a worker's reservation wage while unemployed is:

$$
r=b+\left(\kappa_{0}-\kappa_{1}\right) \int_{r}^{\infty}\left[\frac{1-F(w)}{1+\kappa_{1}(1-F(w))}\right] d w
$$

where $F(w)$ is the wage offer distribution, $\kappa_{0}=\lambda_{d} /\left(\delta+\eta_{1}\right)$ and $\kappa_{1}=\lambda_{1} /\left(\delta+\eta_{1}\right)$, and $b$ is the value of non-market time. ${ }^{3}$ Ex ante workers are homogeneous in that $b$ is assumed to be the same across all workers. ${ }^{4}$ The

\footnotetext{
${ }^{3} \mathrm{~b}$ is the value of non-market time while in the unemployment state. Equation (1) is independent of the value of non-market time in the non-participation state.
} 
reservation wage while employed is the current wage. Thus a worker accepts a new job if and only if the wage offer exceeds her state-dependent reservation wage.

Following Mortensen (1990) firms face constant returns to scale production functions and optimize by choosing a wage offer distribution that maximizes profits. Profits are equal to:

$$
\pi(w)=(P-w) l(w)=(P-w) \lambda_{0}\left(\frac{\eta_{2}}{\eta_{1}+\eta_{2}}\right)\left(\frac{1}{1+k_{0}}\right)\left[\frac{\left(\eta_{1}+\delta+\lambda_{1}\right) M}{\left(\eta_{1}+\delta+\lambda_{1}(1-F(w))\right)^{2}}\right]
$$

where $P$ is per worker productivity, $l(w)$ is the number of workers per firm paying wage $w$, and $M$ is the measure of workers. Imposing the equal profit condition allows one to solve for $F(w)$, which is a nondegenerate distribution due to the competition between firms for employed workers. Offering wages higher than the reservation wage attracts more workers to a firm and retains them longer. Thus $l(w)$ is increasing in w. Firms offer higher wages if and only if they expect to get enough additional workers to cover the lower per worker profit. Mortensen shows the equilibrium wage offer distribution is unique and in this 3-state model it is given by:

$$
F(w)=\frac{1+\kappa_{1}}{\kappa_{1}}-\frac{1+\kappa_{1}}{\kappa_{1}}\left[\frac{P-w}{P-w_{L}}\right]^{1 / 2}, \quad w_{L} \leq w \leq w_{H}
$$

where $w_{L}$ is the lowest wage offered by a firm and $w_{H}$ is the highest wage paid by a firm. The model implies the following restrictions: $w_{L}=r, F(r)=0$, and $F\left(w_{H}\right)=1$. The only difference in the solution for $F(w)$ between this model and Mortensen's is in the definition of $\kappa_{1}$. In his version $\kappa_{1}=\lambda_{1} / \delta$, while here $\kappa_{1}=\lambda_{1} /\left(\delta+\eta_{1}\right)^{5} F(w)$ is the wage offer distribution and is not the same as the cross-section earnings distribution of workers, as over time workers tend to move up the wage range. Thus the earnings

${ }^{4}$ Heterogeneous workers are allowed in Mortensen's (1990) setting, but estimation methods have yet to be developed for this case.

${ }^{5}$ This is fairly straightforward since in the 2-state model $\eta_{1}$ is implicitly assumed to be zero and in the 3-state model $\delta$ and $\eta_{1}$ have the same effect on the firm. Both result in a job separation and neither is preventable by the firm. 
distribution lies to the right of the offer distribution. Let $G(w)$ be the earnings distribution. It is given by the following formula:

$$
G(w)=\frac{F(w)}{1+K_{1}(1-F(w))}
$$

The parameters $\kappa_{0}$ and $\kappa_{1}$, important components of $r, F(w)$ and $G(w)$, can be thought of as relative measures of how much competition there is among firms for unemployed and employed workers. An increase in the job offer arrival rates raises the level of competition while increases in job loss or personal exit rates lower competition.

Given the above model there are several ways one might think about analysing the effect of behavioural differences across the sexes on the wage distribution. An obvious starting point is to assume men and women operate in the same labour market and exhibit the same behavioural patterns and then estimate the above model using data on both sexes. With this case as a benchmark one could then examine alternatives which allow for differences across gender. One alternative is to assume that men and women operate in the same labour market and therefore have the same job offer arrival rates and job destruction rate, as well as the same productivity level, but exhibit different behavioural patterns with respect to personal exits to non-participation. This amounts to assuming $\lambda_{0}, \lambda_{1}, \delta$ and $P$ are the same across gender, but $\eta_{1}$ and $\eta_{2}$ are not. In this case men and women will have different reservation wages since $\eta_{1}^{F} \neq \eta_{1}^{M}$. Under the assumption $\eta_{1}^{F}>\eta_{1}^{M}$, women will have a lower reservation wage than men. This, along with the fact that women will move up the wage distribution slower than men, leads to a lower average wage for females. Solving the model for this case requires keeping track of men and women separately. The labour supply function is now a convex combination of the labour supplies of males and females, each dependent on both the labour market and the gender-specific behavioural parameters. Unfortunately imposing the equal profit condition does not lead to an analytical solution for $F(w)$ as in the common parameter case. 
In this paper I explore another alternative which also allows for behavioural differences across the sexes. I assume that men and women operate in separate labour markets and estimate the model separately for men and women. This case follows under the notion that jobs are segregated. That is, for 'female' jobs firms only concern themselves with the behavioural patterns of and the outside competition for females when setting wage policy for those jobs and likewise for male jobs. It is still true in this case that $\eta_{1}$ and $\eta_{2}$ are allowed to differ across the sexes, but now the market parameters $-\lambda_{0}, \lambda_{1}, \delta$ and $P$ are also allowed to vary. All can potentially contribute to the explanation of male-female wage differentials.

\section{ESTIMATION METHOD}

Identification of the parameters of this model requires panel data: specifically data on wages, job spell durations, job exit transitions and non-employment durations. For the 3-state model the job exit transition data must not only distinguish between exits to non-employment and exits to alternative employment, but must further separate the exits to non-employment into those to unemployment and those to non-participation. Given the transitions allowed in the model, identification requires the knowledge of only the state at the start of the non-employment spell and not the duration and sequence of states within each spell.

The likelihood function is formed by taking the product of the likelihoods of each of the data elements mentioned above. Since I examine the accepted wage for the first full-time job after graduation, wages are distributed as $f(w)$, the probability density function (pdf) of the wage offer distribution $F(w)$. Because firms offer wages equal to or above the reservation wage in each market, all wage offers received while unemployed are acceptable and there is no need to condition on the wage being higher than $r$.

Assuming the arrival processes are Poisson leads to the following conditional (on wages) distribution of job spell lengths: 


$$
f_{f}(t w)=\left[\delta+\eta_{1}+\lambda_{1}(1-F(w))\right]^{(1-\alpha)} \exp \left(-\left[\delta+\eta_{1}+\lambda_{1}(1-F(w))\right] t\right)
$$

where $d$ is an indicator variable that takes on a value of 1 if the spell is censored. Thus a job can end due to destruction, $\delta$, a personal need, $\eta_{1}$, or because of a better job offer, $\lambda_{1}(1-F(w))$. The last component is made up of two parts: the likelihood of receiving a job offer while employed and probability of it being accepted, i.e. a wage offer higher than the current wage w. The non-employment durations are also exponentially distributed. Given the assumption that one must transit from non-participation to unemployment, the average length of non-employment spells that start in non-participation is greater than those starting in unemployment. To see this, note that the means of the two types of non-employment spells are:

$$
\begin{aligned}
& E(t \mid S=0)=\frac{1}{\lambda_{0}+\eta_{1}}+\frac{\eta_{1}}{\lambda_{0}+\eta_{1}}\left[\frac{1}{\eta_{2}}+E(t \mid S=0)\right] \\
& \Rightarrow E(t \mid S=0)=\frac{\eta_{1}+\eta_{2}}{\lambda_{0} \eta_{2}} \\
& E(t \mid S=1)=\frac{1}{\eta_{2}}+E(t \mid S=0)=\frac{\lambda_{0}+\eta_{1}+\eta_{2}}{\lambda_{0} \eta_{2}}
\end{aligned}
$$

where $S$ equals 1 if the spell starts in non-participation. Thus the contribution of the non-employment durations is given by the following conditional distributions:

$$
\begin{gathered}
f_{N E}(t \mid S=0)=\left[\frac{\lambda_{0} \eta_{2}}{\eta_{1}+\eta_{2}}\right]^{(1-d)} \exp \left(-\left\{\lambda_{0} \eta_{2} J\left(\eta_{1}+\eta_{2}\right)\right\} t\right) \\
f_{N E}(t \mid S=1)=\left[\frac{\lambda_{0} \eta_{2}}{\lambda_{0}+\eta_{1}+\eta_{2}}\right]^{(1-\alpha)} \exp \left(-\left\{\lambda_{0} \eta_{2}\left(\lambda_{0}+\eta_{1}+\eta_{2}\right)\right\} t\right)
\end{gathered}
$$

where again $d$ is a dummy variable indicating censoring. This distinction identifies $\eta_{2}$ and $\lambda_{0}$.

The final contribution to the likelihood function is the transition probabilities. There are three of these, as one can transit from a job to job, to unemployment, or to non-participation, and all are 
conditioned on the current wage.

$$
\begin{gathered}
P(S=0, C=0 \mid w)=\frac{8}{8+\eta_{1}+\lambda_{1}[1-F(w)]} \\
P(S=1, C=0 \mid w)=\frac{\eta_{1}}{8+\eta_{1}+\lambda_{1}[1-F(w)]} \\
P(C=1 \mid w)=\frac{\lambda_{1}[1-F(w)]}{8+\eta_{1}+\lambda_{1}[1-F(w)]}
\end{gathered}
$$

where $C$ is equal to 1 if the exit is to another job rather than non-employment.

Thus given panel data on wages, w; job durations, $D_{j}$; non-employment durations, $D_{\mathrm{NE}}$; and transitions the likelihood function is made up of four parts: the accepted wage, $f(w)$; the duration of the job conditional on earning $w, f_{j}\left(D_{\jmath} / w\right)$; the duration of non-employment conditioned on the state at the start, $f_{N E}\left(D_{N E} \mid S\right)$; and the probability of the job ending due to destruction, personal reasons or another job, $\mathrm{P}(\mathrm{S}, \mathrm{Clw})$. The likelihood function is the product of these four terms:

$P(\theta)=\theta\left(\lambda_{0}, \lambda_{1}, \delta, \eta_{1}, \eta_{2}, P_{1}, \ldots, P_{Q}, \mathbf{r}, w_{\mathrm{H} 1}, \ldots, w_{\mathrm{HQ}}, \gamma_{1}, \ldots, \gamma_{Q_{-1}}\right)$

$f(\theta)=f(w) \exp \left(-\left(\delta+\eta_{1}+\lambda_{1}[1-F(w)]^{*} D_{f}\right)\right)[\delta]^{(1-\mathcal{C})(1-S)}\left[\eta_{1}\right]^{(1-\mathcal{C}) \cdot s}\left[\lambda_{1}[1-F(w)]\right]^{c}$

$\left[\left(\lambda_{0} \eta_{2} /\left(\lambda_{0}+\eta_{1}+\eta_{2}\right) \exp \left(-\lambda_{0} \eta_{2} * D_{N E} /\left(\lambda_{0}+\eta_{1}+\eta_{2}\right)\right)\right]^{(1-C) S} *\left[\left(\left(\lambda_{0} \eta_{2} /\left(\eta_{1}+\eta_{2}\right) \exp \left(-\lambda_{0} \eta_{2} * D_{\mathrm{NE}} /\left(\eta_{1}+\eta_{2}\right)\right)\right]^{(1-C)(1-S)}\right.\right.\right.$

where for convenience I have left out the appropriate measures one must take to deal with censored employment and non-employment spells.

Results in Bowlus, Kiefer and Neumann (1995a) indicate a poor fit between the wage distribution implied by the homogeneous version of the model given in Section II and the wage data. They show that adding firm heterogeneity through variation in productivity levels greatly improves the model's fit of the wage data. Thus when estimating the model I assume there are $\mathrm{Q}$ firm types which can be ordered as 
$\mathrm{P}_{1}<\mathrm{P}_{2}<\ldots<\mathrm{P}_{\mathbf{Q}}{ }^{6}$ The solution under firm heterogeneity results in a complete segmentation of the wage offer range among firm types. Low productivity firms occupy the lower range of wages while high productivity firm types find it optimal to pay higher wages.' In this case equal profits within but not across firm types is required in equilibrium. The equilibrium wage offer distribution in the wage range for firm type $\mathrm{j}$ is given by:

$$
F_{j}(w)=\frac{1+\kappa_{1}}{\kappa_{1}}-\frac{1+\kappa_{1}\left(1-\gamma_{j-1}\right)}{\kappa_{1}}\left[\frac{P_{j}-w}{P_{j}-w_{L j}}\right]^{1 / 2}, \quad w_{L j} \leq w \leq w_{H j}
$$

where $\gamma_{j}$ is the fraction of firms with productivity $P_{j}$ or less, $w_{L j}$ is the lowest wage offered by a firm of type $\mathrm{j}$, and $\mathrm{w}_{\mathrm{Bj}}$ is the highest wage paid by a type-j firm. The model implies the following restrictions: $w_{L_{1}}=r$ and $F(r)=0 ; w_{B j}=w_{L j+1}$ and $F\left(w_{B j}\right)=\gamma_{j}, j=1, \ldots, Q-1 ;$ and $F\left(w_{B Q}\right)=1$. The restriction $F\left(w_{B j}\right)=\gamma_{j}$ leads to the following relationship between the productivity levels, the wage cuts and the fraction of firms of each type:

$$
P_{j}=\frac{w_{H j}-B_{j} w_{H j-1}}{1-B_{j}} \text { where } B_{j}=\left[\frac{1+\kappa_{1}\left(1-\gamma_{j}\right)}{1+\kappa_{1}\left(1-\gamma_{j-1}\right)}\right]^{2}
$$

Following Bowlus, Kiefer, and Neumann (1995b) (BKN) I replace the P's in the likelihood function with the expression in (14). The likelihood is now a function of the rates and the wage cutoffs with their respective $\gamma$ 's. There are actually kinks at the wage cuts in $F(w)$ and therefore $f(w)$ and $f(\theta)$ are discontinuous at these points. BKN show the maximum likelihood estimates for $r$ and $w_{\mathrm{HQ}}$ are the sample minimum and maximum, respectively, and those for $\mathrm{w}_{\mathrm{H} 1}, \ldots, \mathrm{w}_{\mathrm{HQ}-1}$ come from the set of observed

\footnotetext{
G use a discrete distribution for the heterogeneity because with a continuous distribution there is a direct map between the distribution chosen and the resulting wage distribution due to the competition faced on either side by any one firm. Explaining all wage variation through assumptions about heterogeneity does not get at the questions posed in this paper. Differences in firms across the sexes are treated in this paper as residual wage differences that cannot be explained by arrival rate differences.

${ }^{7}$ One justification of the differing productivities comes from the human capital framework where training investments are made by firms where turnover is low.
} 
wages. Rather than searching over all possible wage cut combinations, BKN employ Simulated Annealing which searches over the possible combinations and stops according to an optimal stopping rule. ${ }^{8}$ These estimators of the $w_{\mathrm{B}}$ 's are super-convergent and therefore can be treated as known when estimating the remaining parameters using standard maximum likelihood techniques. Thus the estimation is actually done by iterating over a two-step procedure. First, holding all of the arrival rates fixed, $w_{\mathrm{B} 1}$ through $\mathrm{w}_{\mathrm{BQ}-1}$ are estimated from the set of observed wages using Simulated Annealing to search over the possible combinations. $\gamma_{1}$ through $\gamma_{Q_{-1}}$ are estimated off of the empirical cumulative density function (CDF) during this procedure. Once a wage cut combination has been found that maximizes the likelihood function given the fixed rates, the wage cuts and their respective $\gamma$ 's are held fixed and standard maximization procedures are used to estimate the rates. Iterations of this procedure are conducted until convergence is achieved. $Q$ is chosen by comparing the improvement in the log likelihood function with the addition of firm types. Since the exact distribution of the difference in log likelihood values is yet to be worked out, I follow BKN and compare 2 times the change to Chi-square critical values.

\section{DATA}

To estimate the model, panel data rich in work history information at the job spell level is needed. To this end I use the NLSY's 1979-1991 cross-sectional and supplemental samples. All respondents were between the ages of 14 and 22 in 1979 . Interviews were conducted yearly, and in each year respondents report up to five jobs they hold currently or have held over the last year. If a respondent holds a job over more than one interview, that job is listed multiple times. The NLSY Workhistory data provide a means of linking these entries resulting in only one observation for each job held. Unpaid leaves during a job spell are recorded as well as transition times between jobs. In my sample unpaid leaves must last longer

\footnotetext{
${ }^{8}$ Given the size of the data sets in this paper searching over all possible combinations becomes computationally time-intensive at $Q$ levels beyond two.
} 
than 3 months before they are termed a separation and treated as a non-employment spell. Those shorter than 3 months are counted in the final tenure of the job spell. This is done to stay within the definitions laid out in Section II. In particular, $\delta$ is a permanent job separation rate which forces workers into unemployment where they must search for new jobs, and $\lambda_{0}$ is the arrival rate of new job offers, not the rate at which workers are recalled or strikes are settled. Similarly $\eta_{2}$ is the rate at which workers return to search after a personal need is resolved, not the rate at which maternity or family leaves expire.

Because the model assumes that firms operate in a common labour market, I need to make the sample as homogeneous as possible. To do this I first divide the respondents by education. From the information given on educational attainment in the NLSY I can reasonably assign a last date and level of schooling for each respondent. In this way I do not have a high school dropout competing with a college graduate. For this study I have chosen to restrict my attention to two education groups: those with a high school degree and no more and those with at least sixteen years of completed education labelled college graduates. I have also restricted the sample to white respondents. Among the white respondents there are 1306 male high school graduates, 1468 female high school graduates, 749 male college graduates, and 795 female college graduates. To reduce the variation in experience I look at the first full-time employment spell, 35 hours/week or more, within three years after the completion of the individual's education. To make sure I have the first full-time job after graduation I include only those individuals who finished school after January 1, 1978.9 If the first full-time job spell happens to surround the education date, it is used as the first spell only if the individual holds the job longer than two months after the education date and the job started less than a year before. Otherwise, the next full-time employment spell, if there is one within three years of the education date, is used. This eliminates summer jobs and temporary jobs held while in school and jobs that were accepted with quite different educational

\footnotetext{
${ }^{9}$ Reconstructing the employment history prior to $1 / 1 / 78$ is not possible. This restriction has hardly any effect on the sample size of the college graduates because most of them finish after 1978, but it does reduce the sample size considerably for high school graduates to 1009 males and 1058 females.
} 
qualifications. 814 high school males, 822 high school females, 549 college males and 532 college females have first jobs that meet these requirements.

For the non-employment data I use the jobless spells of individuals who do not exit to other jobs following the above job spells. I do not use the jobless spells following graduation, as used by Kiefer and Neumann (1993), because the necessary information on whether or not the spells start in unemployment or non-participation is not available. The jobless spell gives the duration between the end of the first fulltime job and the start of the next primary job, where primary jobs consist of twenty hours or more per week, last longer than three weeks and are not encompassed by other spells. ${ }^{10}$ The state of the jobless spell at its start, non-participation or unemployment, is determined off the 'why did you leave this job' question for the prior employment spell. Individuals who responded that they left their jobs for family, health or pregnancy reasons have non-employment spells coded as non-participation while those who cited job-related reasons are coded as unemployed. ${ }^{11}$ It is possible due to attrition and the finite sampling period for either the employment or non-employment spell to be censored. For the employment spell the censoring date is the one given by the respondent in the NLSY. For the non-employment spell it is the last date the individual interviewed with NLSY. These censored non-employment spells are likely to be

\footnotetext{
${ }^{10}$ I use twenty hours per week as the criteria rather than thirty-five to distinguish between those individuals who spend most of their time searching and receive offers at rate $\lambda_{0}$ and those who work more and may receive offers at some rate between $\lambda_{0}$ and $\lambda_{1}$. Sensitivity analysis to this assumption revealed the differences in average non-employment durations are surprisingly small as one lowered the hours restriction to zero. Significantly larger average non-employment durations are found if the hours restriction is raised to 35 .

${ }^{11}$ Given the assumptions made so far it would be difficult to go beyond this distinction and use actual non-participation and unemployment spell data. For each non-employment spell between jobs listed by the respondent the NLSY reports the number of weeks the respondent searched. They do not report the order or timing of unemployment spells. In addition the time spent in non-primary jobs, which is also included in my non-employment duration measure, would have to be accounted for in some way.
} 
long and include primarily women who have exited from the labour force on a more or less permanent basis. $^{12}$ All durations are in weeks.

It is possible for an employment/non-employment spell series to be inadmissible. This occurs if either one of the spells has an erroneous start or stop date. ${ }^{13}$ These spell series are excluded as well as all those with job spells that are not in the private sector and those with missing wages or hours, or no response to the 'why did you leave' question. Data on wages in the NLSY are categorized according to time rates: hourly, daily, weekly, bi-weekly, monthly, and annually. Each time a respondent is questioned about a job wage information is collected. For this study the first wage reported for the job in question is used as the accepted wage offer. All wages are converted into weekly wages to match the duration measures and past search studies such as Eckstein and Wolpin (1990), van den Berg and Ridder (1993a,1993b) and Kiefer and Neumann (1993). Close to 50\% of the high school graduates and $75 \%$ of the college graduates report wages in time units other than hourly. ${ }^{14}$

Some concern needs to be taken with the wage information reported by the NLSY. Several cases can be found where a respondent reports a time rate that does not agree with the pay rate. For example, there is a female high school graduate who reports a weekly wage of $\$ 9$ and at the other extreme a male college graduate who reports an hourly wage rate of $\$ 19,000$. To identify these problem responses I cross check all time and pay rate responses against upper and lower bounds collected for males and females of the same age and education from the Current Population Surveys (CPS) for 1979-1991. ${ }^{15}$ Those

\footnotetext{
${ }^{12}$ Given the maximum age in the sample of 33 , it is likely that some of these women are starting to finish their child rearing and in a few more years will be looking to return to the labour force.

${ }^{13} \mathrm{~A}$ few spells in the data have no start and/or no stop dates and a few have start dates which are greater than their stop dates.

${ }^{14}$ The analysis with hourly wages is available from the author in an Appendix upon request. The conclusions reached under both measures are the same.

${ }^{15}$ I use the 5th and 95th percentiles from the set of hourly wages for paid hourly workers from the March outgoing rotation groups for each year. This avoids wage conversion problems also present in the
} 
respondents with wages that do not fall within the acceptable ranges are dropped from the sample. This leaves me with a sample of 589 male high school graduates, 585 female high school graduates, 388 male college graduates and 358 female college graduates. During the estimation of the model I trim $5 \%$ off the top end of the wage distributions which tend to be thin and cover wide ranges. The model has a difficult time reconciling these observations with the majority seen in the data. The best it can do is attach different firm types to each of these wages. This results in a chopping of the right tails into different firms types and sometimes, as shown later, implausible productivity values. I have chosen a trim level at which this does not occur and the productivity values seem reasonable. The choice of a trim level does, of course, have a direct effect on the estimate of $\mathrm{w}_{\mathrm{HQ}}$, but sensitivity analysis done with no trimming and a 3\% trim level reveals the parameters and conclusions of interest are robust. A complete breakdown of the effect of each restriction on the sample sizes is given in Appendix A.

The above restrictions yield a data set that is fairly homogeneous in terms of measurable characteristics. The mean age is $\mathbf{1 8 . 8}$ for the high school graduates and 23.9 for the college graduates; and $12.5 \%$ of the high school sample are married compared to $19.6 \%$ of the college sample. Table 1 shows the means of the variables of most interest for this study. ${ }^{16}$ The second row in the table shows the average weekly wage in 1990 constant dollars. Female high school graduates earn on average $79.8 \%$ of their male counterparts, while female college graduates earn slightly more at $81.6 \% .{ }^{17}$ Figure 1 shows another view of the wage differences across the four groups by comparing the empirical CDF's of accepted wages. In each case the male CDF lies completely to the right of its female counterpart.

CPS. The lower bounds are quite close to the minimum wage. The bounds and procedure are outlined in Appendix A.

${ }^{16}$ Due to the oversampling of poor whites in the NLSY's supplemental sample, I have calculated weighted means using the 1979 sample weights.

${ }^{17}$ See Cain (1986) for a comparison of estimated male-female wage differentials. 
The third row of Table 1 shows mean job durations for non-censored spells. Censoring, shown in row 5 , is around $8 \%$ for high school graduates, and $22-34 \%$ for college graduates. ${ }^{18}$ The fraction of non-employment spells that began in non-participation is shown in row 6. Females have a substantially higher fraction for both education groups. Mean durations of non-employment spells, conditioned on the state at the start (unemployment or non-participation), are shown in rows 7 through 10 of the table. Men exhibit shorter non-employment durations than women, especially for spells that start in non-participation. Female non-participation spells last much longer than female unemployment spells, while for men there is little difference. The non-participation spells are even shorter than are spells of unemployment for male high school graduates. The final row of the table shows the probability that a person who has lost or left a job transits to another job rather than into non-employment. For high school graduates this figure is significantly higher for men, but the difference is insignificant for college graduates.

\section{RESULTS}

The results from estimating the model under the common labour market assumption are shown in columns 1 and 4 of Table 2 for high school and college graduates, respectively. ${ }^{19}$ For the case of separate labour markets the results are shown in columns 2 and 3 of the table for high school graduates and 5 and 6 for college graduates. Because the mean of non-employment spells that start in nonparticipation is smaller than that for spells that start in unemployment for male high school graduates, $\eta_{2}$ is not identified for this group. I estimate the model for them under the assumption that the exit rate out of non-employment is the same regardless of the state at the start and is equal to the exit rate out of

\footnotetext{
${ }^{18}$ The level is much higher for the college graduates because, given their age at the start of the survey, they finish school later in the sample period and therefore are more likely to have their first admissible spell censored due to the end of the sampling period.

${ }^{19}$ In all of the estimations I use the 1979 sample weights to correct for the oversampling of poor whites. In all cases the parameter estimates are insignificantly different from the ones obtained without using the sample weights.
} 
unemployment, $\lambda_{0}$. The null hypothesis that the parameters are the same across the sexes is rejected for both education groups. ${ }^{20}$ The parameter values across the sexes are significantly different.

In most instances in Table 2 the males have higher job finding rates and lower job destruction/separation rates than the females. ${ }^{21}$ This evidence supports Lazear and Rosen's (1990) model of lower promotion rates for women and their positive effect on the male-female wage differential. An implication from their model, borne out in the results presented, is that higher educated females should not see as great a reduction in promotion rates as lower educated females. Here college women actually face a higher $\lambda_{1}$ than their male counterparts. As noted above, $\kappa_{1}$ - the ratio of the job offer arrival rate while employed to the job loss and personal separation rates -is an important determinant of the wage offer distribution. Its counterpart for unemployed searchers, $k_{0}=\lambda_{\sigma}\left(\delta+\eta_{1}\right)$, is also important through its influence on the reservation wage. ${ }^{22}$ The values of $k_{0}$ and $k_{1}$ are shown in rows 6 and 7 of Table 2 . Comparing competition by gender, I find that males face higher relative competition levels in both education categories, with the largest difference occurring for $k_{0}$ for college graduates. Note that college graduates of either sex face higher competition levels than their high school counterparts.

Table 3 highlights the importance of using a 3-state model, especially for females, by showing the estimation results for Mortensen's 2-state model. Estimates of $\lambda_{0}$ and $\delta$ are significantly lower and higher, respectively, for females in the 2-state model. The estimate of $\delta$ is biased upward because in the 2-state model all personal exits are attributed to job destruction, and that for $\lambda_{0}$ is biased downward as the longer non-participation spells are included with the unemployment spells. As shown in row 4 of Table 3 this

\footnotetext{
${ }^{20}$ For the college graduates a likelihood ratio test can be conducted while for the high school graduates this is not possible due to the non-identification of $\eta_{2}$ for males. Individual equality tests of the parameters reveal that $\lambda_{1}, \delta$ and $\eta_{1}$ are significantly different across the sexes for this group.

${ }^{21}$ For job leaving rates not due to outside firm competition add $\delta$ and $\eta_{1}$.

${ }^{22}$ The reservation wage is a function of both $\kappa_{0}$ and $\kappa_{1}$. The higher $\kappa_{0}\left(\kappa_{1}\right)$ the higher (lower) the reservation wage of the workers as they see their best opportunity for finding a job coming from the unemployed (employed) search state.
} 
results in much lower values of $k_{0}$ in the 2-state model for the female groups. For males this is not true as $\kappa_{0}$ and $\kappa_{1}$ are basically the same across the two models for both groups. ${ }^{23}$ In fact in the 3-state model for male college graduates $\eta_{1}$ is not even significantly different from zero. ${ }^{24}$ Thus suggesting that for males the 2-state model would have been adequate.

Table 4 shows the wage cuts and their respective $\gamma$ 's for the 3-state model under the separate labour market case. The optimal choice of $Q$ is 3 for all four groups. ${ }^{25}$ Note the variation in the reservation wages amongst the different groups. For both education levels the reservation wage is lower for females. This is in line with the finding of higher separation rates for females. Reservation wages are higher for college graduates than high school graduates regardless of sex, which corresponds with increased competition levels across the education categories. At the other end, the highest female wage in both groups is well below those of the males.

Table 5 lists the productivity levels calculated according to equation (14). The last row shows the average productivity level for each group. The differences in the productivity levels across the sexes are analogous to a gender dummy in a regression framework. The model cannot attribute the entire wage differential to differences in behavioural patterns and competition levels and therefore must find another dimension on which to have males and females differ. The only dimension left is productivity. The average productivity level for female college graduates is $\mathbf{8 3 . 8 \%}$ of that for males while the difference is even greater for female high school graduates at 74.2\%. Figures 2 and 3 show a graphical representation of these productivity profile differences. Only in the college graduate case does the female profile ever

\footnotetext{
${ }^{23}$ For both male groups the parameter estimates of $\lambda_{0}, \lambda_{1}$, and $\delta+\eta_{1}$ in the 3-state model are not signficantly different from those of $\lambda_{0}, \lambda_{1}$ and $\delta$ in the 2-state model.

${ }^{24}$ There are only 3 male college graduates in the sample that exit employment for personal reasons.

${ }^{25}$ As stated, trimming affects the level of $Q$. With $3 \%$ trimming $Q$ was more likely to be four with at least one $\gamma$ above .95 and with no trimming $Q$ was either 5 or 6 with two or more $\gamma$ 's above .90 . Thus one can see a pattern of needing more firm types and assigning them to the upper end of the wage distribution.
} 
cross the male profile. Figure 4(a-d) shows how well the predicted CDF's fit the empirical CDF's for each group. The model seems to experience the most difficulty in fitting the curvature of the lower left tail. Evidently, labour supply does not increase fast enough in the data to justify the higher wages.

Table 6 presents mean wages and durations as predicted by the model. Comparing row 1 of Table 6 to row 2 of Table 1 I find that the model does a decent job of matching the mean offer wages, although the difficulty in matching the left tail of the distribution results in a slight downward bias. Row 2 of Table 6 shows the predicted means of the model's cross-sectional earnings distribution. The earnings distributions exhibit larger male-female wage differentials than the wage offer distributions.

Predicted means for the various spell types are shown in the last three rows of Table 6. Large differences in average employment durations across the education categories, as well as across gender for the college graduates, are found in row 3. Rows 4 and 5 of the table indicate that on average females have longer jobless spells than males, irrespective of the reason although the difference is more pronounced with the non-participation spells. Females have non-participation spells that last one to five years longer than unemployment spells. The largest difference between non-participation and unemployment spells occurs with female college graduates. I find this to be unexpected since college educated females have more to lose by exiting the labour market than high school graduates. The data for this group show a bimodal distribution in the duration of spells starting due to personal reasons: about half of the spells are uncensored and have a mean close to that of the unemployment spells, while the rest are censored with substantial durations. However, there does not seem to be a common link among these women such as marital status or occupational choice that one could use to stratify the sample nor that could be used by a firm to better determine the likelihood of future behavioural patterns of female workers. $^{26}$

\footnotetext{
${ }^{26} \mathrm{~A}$ significant fraction of the single women in both education groups, $18.4 \%$ for high school and $19.2 \%$ for college, eventually exit their jobs for personal reasons.
} 
What do the behavioural and market differences found in the above analysis imply about malefemale wage differentials? I approach this question in the following way. First, I ask what is the effect on the mean of the female wage distribution if one institutes policies that influence the competition levels faced by women, holding productivity constant. To answer this I recalculate the model under the female productivity profile but with male competition levels, $\kappa_{0}$ and $\kappa_{1}$. Next I ask what effect there is if females change their behavioural pattern and stop exiting to non-participation for personal reasons. In this case I set $\eta_{1}$ to zero for the females and recalculate the model holding all other parameters constant. Tables 7 and 8 present the mean, median and a lower percentile from the wage offer distribution and the mean of the earnings distribution for high school and college graduates, respectively, calculated according to these two 'thought' experiments. Figures 5 and 6 show the resulting wage offer distributions under each analysis plus the original wage offer distributions for males and females.

Notice in the tables that in each instance the reservation wage changes, as it should, in response to the changing conditions in the market. ${ }^{27}$ To solve for the new reservation wage I first solve for the value of non-market time, $b$, using the original female model parameters and the relationship between $\mathbf{r}$ and $b$ given by equation (1). ${ }^{28}$ I then assume that $b$ does not change under the new setting and re-solve for the new reservation wage given the changes in the parameters. The reservation wage increases if the change in $k_{0}$ is greater than the change in $\kappa_{1}$ and decreases if the reverse is true. The latter only happens in the case of female high school graduates under male competition levels.

Table 7 shows the male-female wage differential for high school graduates is lowered only slightly using the male $\mathrm{k}$ values. A larger improvement, although again one that is not very substantial, is made

\footnotetext{
${ }^{27}$ It is also true that all of the wage cuts change in order for the profit-maximization condition to hold under the new setups. The formula for the wage cuts is derived from rearranging equation (14) and solving for $w_{\mathrm{Hi}}$ as a function of $P_{\mathrm{i}}, \boldsymbol{\gamma}_{\mathrm{i}-1}$, and $\mathrm{w}_{\mathrm{Hi}-1}$.

${ }^{28}$ It actually turns out that the value of non-market time is estimated in the college graduate cases to be less than zero. This is somewhat counter-intuitive but has to do with the fact that the model can't reconcile the high productivity values and job finding rates with the low reservation wages.
} 
when $\eta_{1}$ is set to zero. This result is partially due to the differential effect the two experiments have on the reservation wage as well as the similarity in $k_{0}$ values. $k_{0}$ seems to play a particularly important role as Table 8 shows for the college educated. Large increases in $k_{0}$ cause large increases in the reservation wage. For high school graduates $k_{0}$ only increases slightly under both experiments. Thus little ground, as shown in Figure 5, is made up under either experiment for female high school graduates. In terms of the cross-sectional earnings wage differential they gain about 5 percentage points and go from earning $71.4 \%$ of male wages to $76.3 \%$ and $77.1 \%$ under the $k$ and $\eta_{1}$ experiments, respectively.

The results are strikingly different for female college graduates. Table 8 shows that under both experiments the wage differential is substantially reduced. In this case using male competition levels reduces the differential more than eliminating non-participation spells. This is primarily due to the large increases in $k_{0}$ that occur in both cases, in particular the $\kappa$ experiment. These increases cause the reservation wage to increase and hence, at the low end of the wage distribution the females outperform the males. This is easy to see in Figure 6. Overall, females go from earning $79.2 \%$ of male wages to $90.6 \%$ in the $K$ experiment and $85.3 \%$ in the $\eta_{1}$ experiment. And the mean of the wage offer distribution under the $\mathrm{k}$ experiment even surpasses that of the males.

\section{v. CONCLUSIONS}

This paper presents an alternative view of how behavioural patterns can influence the male-female wage differentials. The analysis shows that to adequately capture these behavioural differences in a search framework an extended version of the common 2-state model is needed, one which includes a nonemployment state where search does not occur. I demonstrate how such a state can be incorporated and the model estimated with information only on why an individual leaves a job and the subsequent nonemployment duration; rather than needing the actual durations in the non-participation and unemployment states, often not available in panel data sets. 
The results indicate the incidence of leaving jobs for personal reasons is trivial for males but not so, as expected, for females. And that for males, even if the departure is for personal reasons, the subsequent non-employment spell durations do not differ significantly from the duration of nonemployment spells due to job-related reasons. On the other hand, female non-employment spells following personal exits are substantially longer than those following job-related exits. It has been noted in the literature that these behavioural differences between the sexes may be contributing to male-female wage differentials.

Couching this type of behaviour within the confines of a general equilibrium search model, I analyze the extent to which it and other differences affect the wage distributions of men and women. I find the higher exit rates of women to non-participation have a negative effect on their reservation wages. I also find significant differences in the arrival rates of job opportunities across men and women. These differences in tandem with the job dissolution rates lead to competition differences across the two markets with male markets characterized as more competitive, in terms of firm competition for workers. This, along with the reservation wage differences, drives wages higher for males. These competitive and behavioural differences do explain part of the wage differential, but they cannot account for the entire wage differential. The model explains the rest through differences in the productivity levels faced by males and females.

The final analysis I conduct asks how much of the wage-differential could be eliminated in this setting if, first, females faced the same competition levels as their male counterparts; and, second, if they stopped leaving employment for personal reasons. The results indicate that for the high school graduates neither of these changes causes the differential to be substantially reduced. However, significant reductions are possible under both settings with the college graduates. This suggests that there is room for the provision of services that aid women in staying in the labour force, as well as increase competition among firms for females, to have a positive effect on eliminating the male-female wage differential. 
Figure 1. Comparison of Empirical CDF's of Accepted Wages Across Gender \& Education

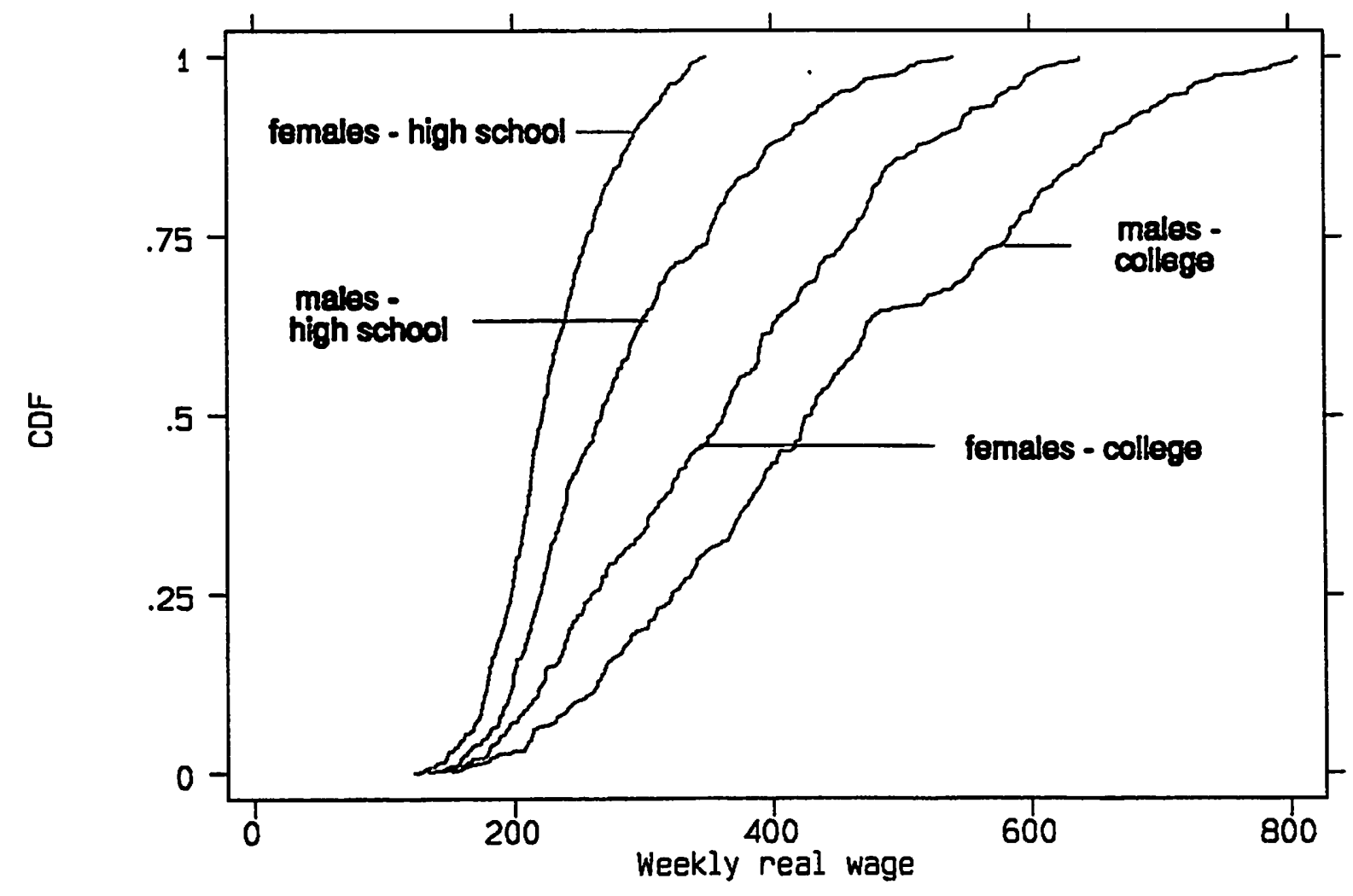


Figure 2. Male and Female High School Graduate Productivity Profiles

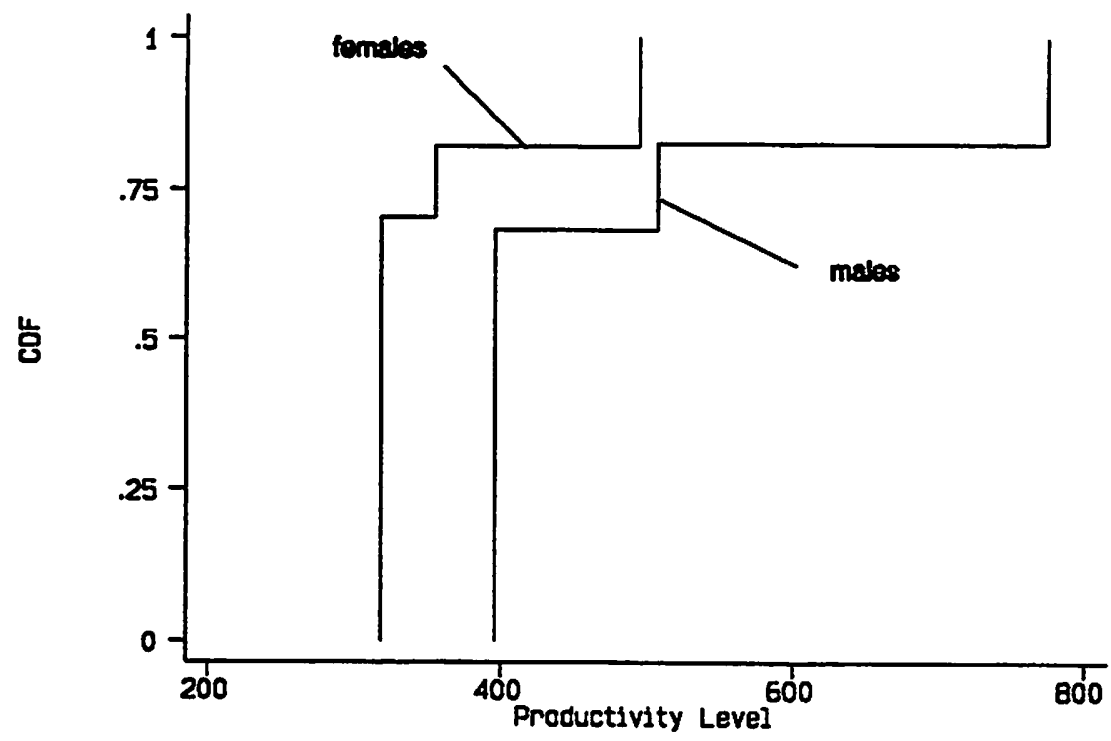

Figure 3. Male and Female College Graduate Productivity Profiles

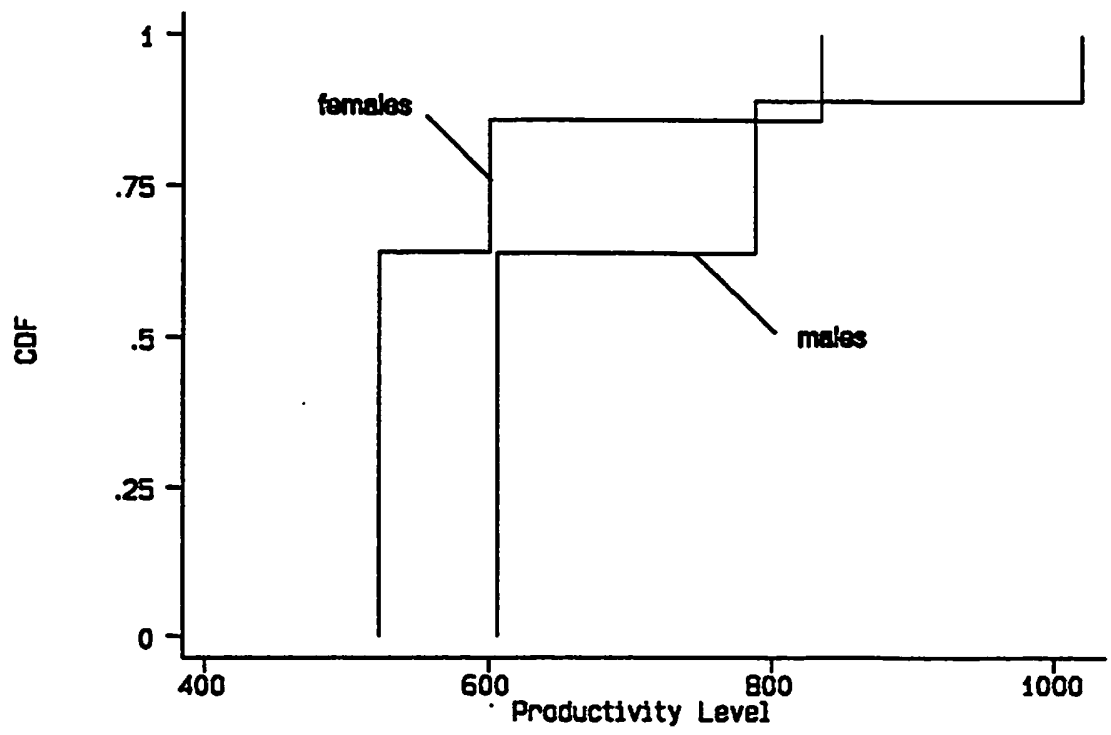


Figure 4. Comparison of Empirical and Estimated CDF's of Accepted Wages

(a) Male High School Graduates

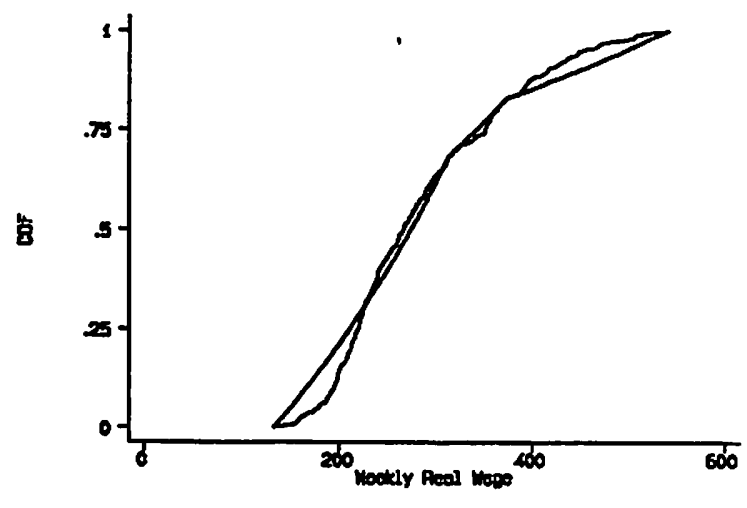

(c) Male College Graduates

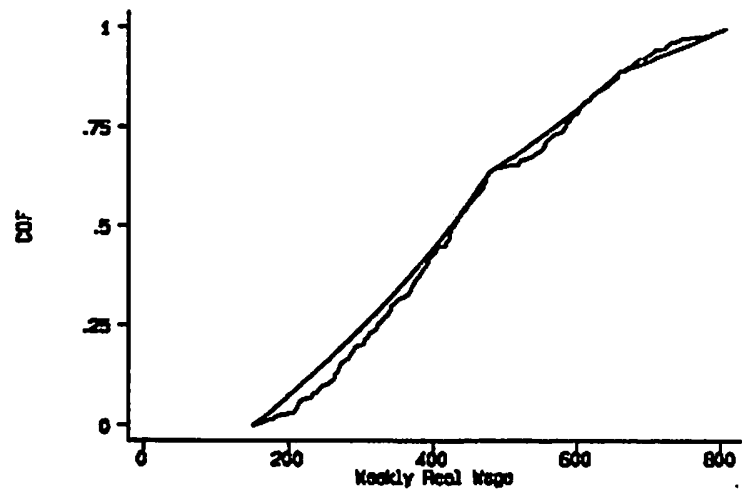

(b) Female High School Graduates

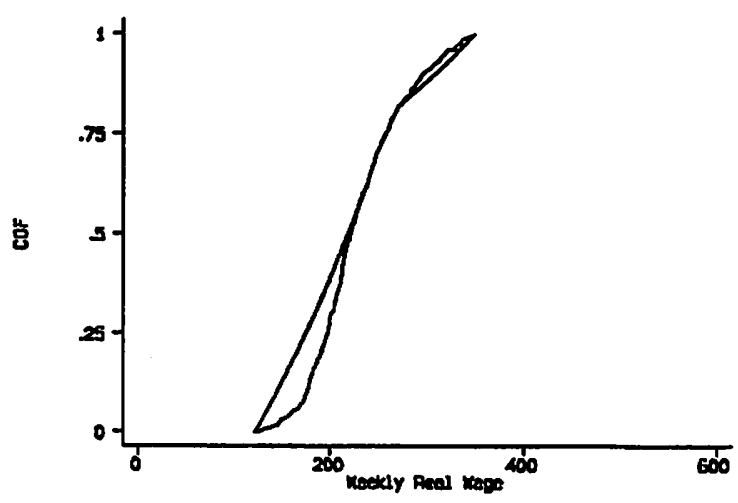

(d) Female College Graduates

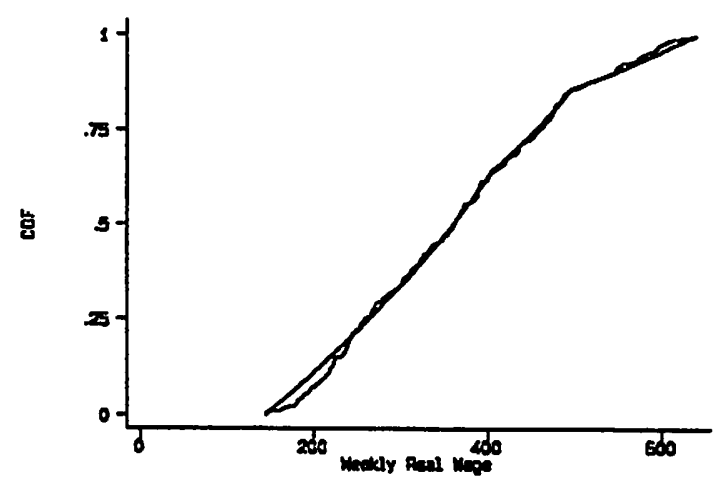


Figure 5. Female High School Graduate Policy Analysis

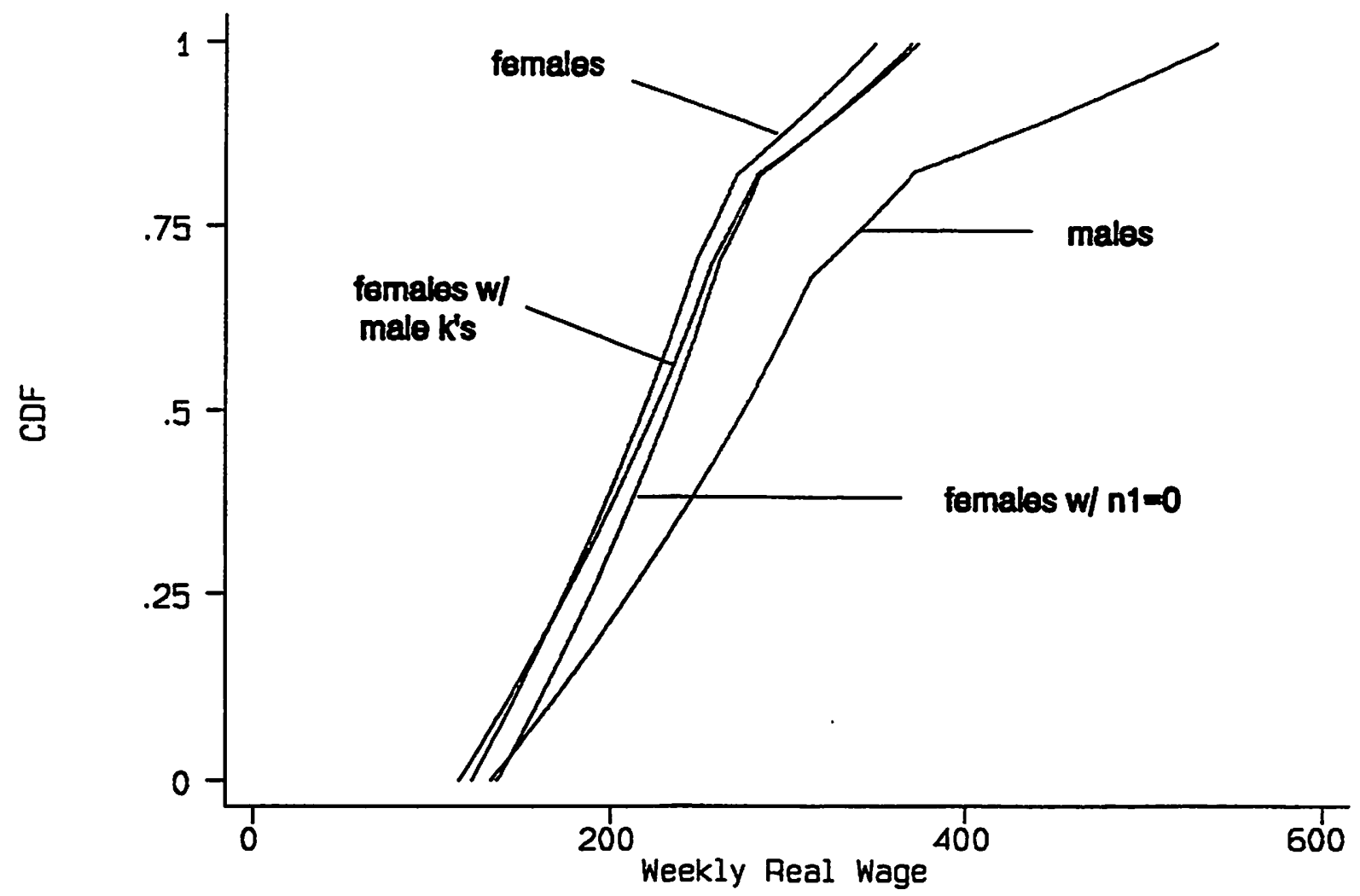


Figure 6. Female College Graduate Policy Analysis

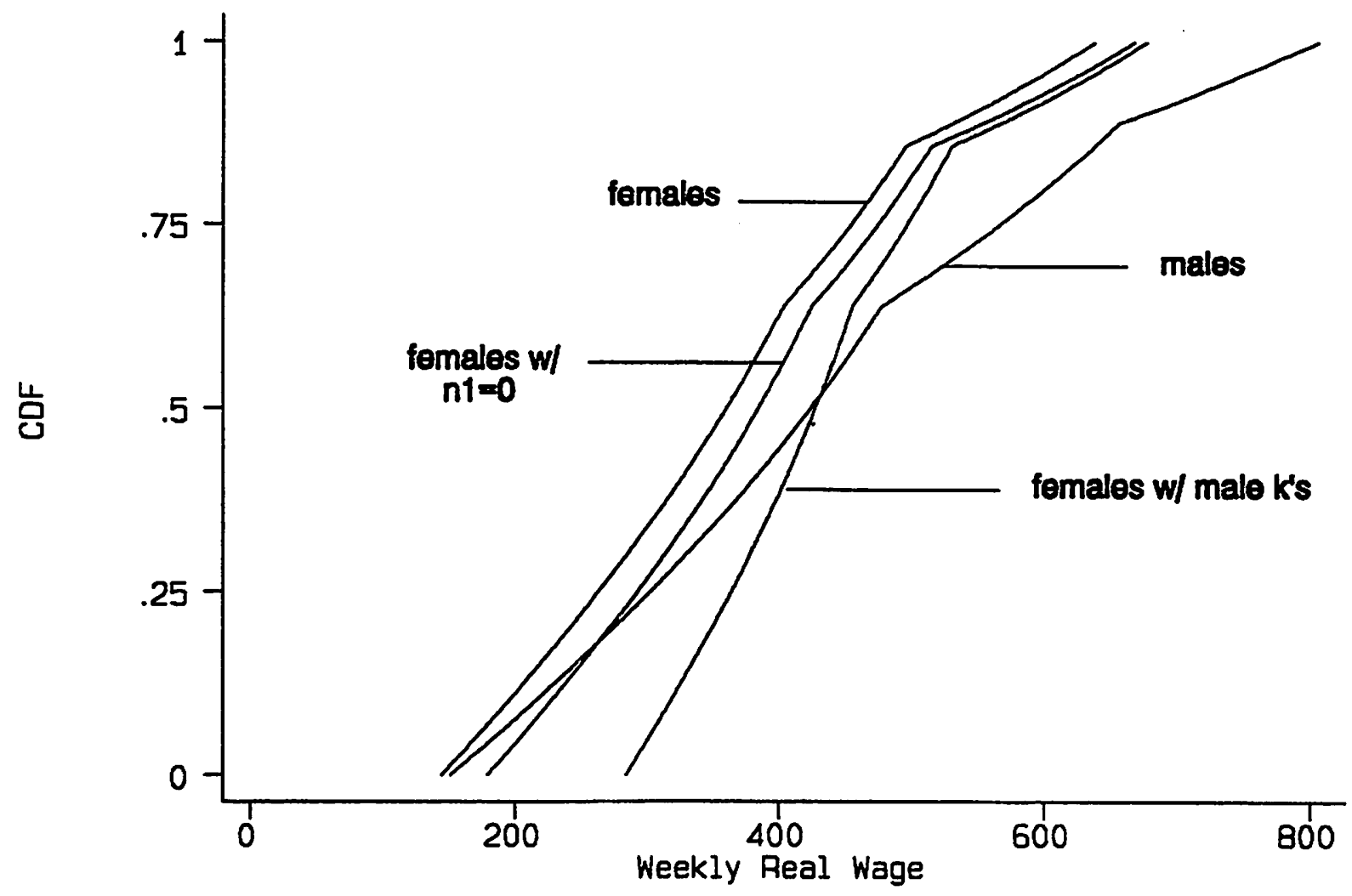


Table 1. Variable Means for White, Privately Employed, Full-time Workers

\begin{tabular}{|c|c|c|c|c|}
\hline & \multicolumn{2}{|c|}{ High School Graduates } & \multicolumn{2}{|c|}{ College Graduates } \\
\hline & Males & Females & Males & Females \\
\hline Number in Sample & 559 & 555 & 368 & 339 \\
\hline Weekly Wage & $\begin{array}{l}287.20 \\
(3.70) \\
\end{array}$ & $\begin{array}{l}229.07 \\
(1.96)\end{array}$ & $\begin{array}{l}448.45 \\
(8.23)\end{array}$ & $\begin{array}{c}365.73 \\
(6.56)\end{array}$ \\
\hline $\begin{array}{l}\text { Job Duration - } \\
\text { (uncensored spells only) }\end{array}$ & $\begin{array}{l}72.62 \\
(4.03) \\
\end{array}$ & $\begin{array}{l}85.19 \\
(4.52)\end{array}$ & $\begin{array}{l}85.45 \\
(5.60)\end{array}$ & $\begin{array}{l}94.40 \\
(5.55)\end{array}$ \\
\hline $\begin{array}{l}\text { Job Duration - } \\
\text { (censored spells included) }\end{array}$ & $\begin{array}{l}95.93 \\
(5.56) \\
\end{array}$ & $\begin{array}{l}108.72 \\
(6.03)\end{array}$ & $\begin{array}{l}132.77 \\
(7.15)\end{array}$ & $\begin{array}{l}112.59 \\
(5.53)\end{array}$ \\
\hline $\begin{array}{l}\text { Rate of Censoring - } \\
\text { Job Durations }\end{array}$ & $\begin{array}{l}0.080 \\
(.012)\end{array}$ & $\begin{array}{l}0.077 \\
(.011)\end{array}$ & $\begin{array}{l}0.336 \\
(.025)\end{array}$ & $\begin{array}{l}0.224 \\
(.023)\end{array}$ \\
\hline $\begin{array}{l}\text { Fraction of Non-emp Spells } \\
\text { that are non-participation at Start }\end{array}$ & $\begin{array}{l}0.021 \\
(.008)\end{array}$ & $\begin{array}{l}0.198 \\
(.022) \\
\end{array}$ & $\begin{array}{l}0.018 \\
(.013) \\
\end{array}$ & $\begin{array}{l}0.187 \\
(.033)\end{array}$ \\
\hline $\begin{array}{l}\text { Non-emp Spell Duration - } \\
\text { unemployed at start } \\
\text { (uncensored spells only) }\end{array}$ & $\begin{array}{l}39.67 \\
(3.86)\end{array}$ & $\begin{array}{l}40.62 \\
(3.99)\end{array}$ & $\begin{array}{l}15.99 \\
(2.60)\end{array}$ & $\begin{array}{l}22.71 \\
(4.31)\end{array}$ \\
\hline $\begin{array}{l}\text { Non-emp Spell Duration - } \\
\text { non-participation at start } \\
\text { (uncensored spells only) }\end{array}$ & $\begin{array}{l}37.81 \\
(5.06)\end{array}$ & $\begin{array}{l}58.16 \\
(8.28)\end{array}$ & $\begin{array}{l}37.01 \\
(16.0)\end{array}$ & $\begin{array}{c}90.29 \\
(41.80)\end{array}$ \\
\hline $\begin{array}{l}\text { Non-emp Spell Duration - } \\
\text { unemployed at start } \\
\text { (censored spells included) }\end{array}$ & $\begin{array}{l}50.78 \\
(5.75)\end{array}$ & $\begin{array}{l}55.51 \\
(6.08)\end{array}$ & $\begin{array}{l}25.81 \\
(5.77)\end{array}$ & $\begin{array}{l}36.46 \\
(6.40)\end{array}$ \\
\hline $\begin{array}{l}\text { Non-emp Spell Duration - } \\
\text { non-participation at start } \\
\text { (censored spells included) }\end{array}$ & $\begin{array}{l}37.81 \\
(5.06)\end{array}$ & $\begin{array}{c}89.44 \\
(12.60)\end{array}$ & $\begin{array}{l}37.01 \\
(16.0)\end{array}$ & $\begin{array}{l}145.72 \\
(28.38)\end{array}$ \\
\hline $\begin{array}{l}\text { Rate of Censoring - } \\
\text { Non-employment Spells }\end{array}$ & $\begin{array}{l}0.033 \\
(.011) \\
\end{array}$ & $\begin{array}{l}0.090 \\
(.016)\end{array}$ & $\begin{array}{l}0.129 \\
(.031) \\
\end{array}$ & $\begin{array}{l}0.180 \\
(.033)\end{array}$ \\
\hline $\begin{array}{l}\text { Fraction of Completed Spells Ending } \\
\text { in a Quit }\end{array}$ & $\begin{array}{l}0.442 \\
(.022)\end{array}$ & $\begin{array}{l}0.336 \\
(.021)\end{array}$ & $\begin{array}{l}0.518 \\
(.032)\end{array}$ & $\begin{array}{l}0.492 \\
(.031)\end{array}$ \\
\hline
\end{tabular}

Note: Standard errors in parentheses. 
Table 2. Parameter Estimates for Arrival Rates Under 3-State Model

\begin{tabular}{|c|c|c|c|c|c|c|}
\hline \multirow[b]{2}{*}{ Parameters } & \multicolumn{3}{|c|}{ High School Graduates } & \multicolumn{3}{|c|}{ College Graduates } \\
\hline & $\begin{array}{l}\text { Males \& } \\
\text { Females }\end{array}$ & Males only & $\begin{array}{l}\text { Females } \\
\text { only }\end{array}$ & $\begin{array}{l}\text { Males \& } \\
\text { Females }\end{array}$ & Males only & $\begin{array}{l}\text { Females } \\
\text { only }\end{array}$ \\
\hline$\lambda_{0}$ & $\begin{array}{l}0.018561 \\
(.000853)\end{array}$ & $\begin{array}{l}0.019264 \\
(.001160)\end{array}$ & $\begin{array}{l}0.017868 \\
(.001225)\end{array}$ & $\begin{array}{l}0.030306 \\
(.002285)\end{array}$ & $\begin{array}{l}0.033373 \\
(.003354)\end{array}$ & $\begin{array}{l}0.028344 \\
(.003313)\end{array}$ \\
\hline$\lambda_{1}$ & $\begin{array}{l}0.008215 \\
(.000394)\end{array}$ & $\begin{array}{l}0.009675 \\
(.000623)\end{array}$ & $\begin{array}{l}0.007385 \\
(.000528)\end{array}$ & $\begin{array}{l}0.006842 \\
(.000413)\end{array}$ & $\begin{array}{l}0.006490 \\
(.000554)\end{array}$ & $\begin{array}{l}0.007778 \\
(.000666)\end{array}$ \\
\hline$\delta$ & $\begin{array}{l}0.004840 \\
(.000205)\end{array}$ & $\begin{array}{l}0.005264 \\
(.000311)\end{array}$ & $\begin{array}{l}0.004428 \\
(.000269)\end{array}$ & $\begin{array}{l}0.002559 \\
(0.00017)\end{array}$ & $\begin{array}{l}0.002297 \\
(.000215)\end{array}$ & $\begin{array}{l}0.002851 \\
(.000273)\end{array}$ \\
\hline$\eta_{1}$ & $\begin{array}{l}0.000628 \\
(.000074)\end{array}$ & $\begin{array}{l}0.000112 \\
(.000046)\end{array}$ & $\begin{array}{l}0.001093 \\
(.000133)\end{array}$ & $\begin{array}{l}0.000296 \\
(.000058)\end{array}$ & $\begin{array}{l}0.000043 \\
(.000029)\end{array}$ & $\begin{array}{l}0.000657 \\
(.000131)\end{array}$ \\
\hline$\eta_{2}$ & $\begin{array}{l}0.020484 \\
(.005816)\end{array}$ & & $\begin{array}{l}0.018915 \\
(.005629)\end{array}$ & $\begin{array}{l}0.004756 \\
(.001468)\end{array}$ & $\begin{array}{l}0.142230 \\
(.514724)\end{array}$ & $\begin{array}{l}0.004107 \\
(.001342)\end{array}$ \\
\hline$k_{0}=\lambda_{d}\left(\delta+\eta_{1}\right)$ & 3.3944 & 3.5839 & 3.2361 & 10.6138 & 14.2628 & 8.0812 \\
\hline$\kappa_{1}=\lambda_{1} /\left(\delta+\eta_{1}\right)$ & 1.5023 & 1.7999 & 1.3376 & 2.3961 & 2.7737 & 2.2176 \\
\hline $\log L$ & -16158.07 & -7925.11 & -8013.40 & -8999.07 & -4498.02 & -4443.38 \\
\hline
\end{tabular}

Note: Standard errors in parentheses.

Table 3. Parameter Estimates for Arrival Rates Under 2-State Model

\begin{tabular}{||l|c|c|c|c||}
\hline \multirow{2}{*}{ Parameters } & \multicolumn{2}{|c|}{ High School Graduates } & \multicolumn{2}{c||}{ College Graduates } \\
\cline { 2 - 5 } & Males & Females & Males & Females \\
\hline$\lambda_{0}$ & $\begin{array}{l}0.019265 \\
(.001160)\end{array}$ & $\begin{array}{l}0.014624 \\
(.000831)\end{array}$ & $\begin{array}{l}0.033199 \\
(.003297)\end{array}$ & $\begin{array}{l}0.014311 \\
(.001374)\end{array}$ \\
\hline$\lambda_{1}$ & $\begin{array}{l}0.009743 \\
(.000627)\end{array}$ & $\begin{array}{l}0.007444 \\
(.000533)\end{array}$ & $\begin{array}{l}0.006449 \\
(.000551)\end{array}$ & $\begin{array}{l}0.007841 \\
(.000672)\end{array}$ \\
\hline$\delta$ & 0.005363 & 0.005513 & 0.002348 & 0.003499 \\
& $(.000314)$ & $(.000300)$ & $(.000217)$ & $(.000302)$ \\
\hline$\kappa_{0}=\lambda_{0} / \delta$ & 3.5924 & 2.6528 & 14.1419 & 4.0902 \\
\hline$\kappa_{1}=\lambda_{1} / \delta$ & 1.8169 & 1.3503 & 2.7473 & 2.2412 \\
\hline
\end{tabular}

Note: Standard errors in parentheses. 
Table 4. 3-State Model Wage Cut Estimates with Respective CDF Values

\begin{tabular}{||l|c|c|c|c|}
\hline \multirow{2}{*}{ Wage Cuts } & \multicolumn{2}{|c|}{ High School Graduates } & \multicolumn{2}{c|}{ College Graduates } \\
\cline { 2 - 5 } & Males & Females & Males & Females \\
\hline $\mathrm{R}$ & 133.3333 & 122.5183 & 151.5152 & 144.9275 \\
\hline $\mathrm{WH}_{1}$ & 312.9346 & 248.5090 & 477.7416 & 404.6555 \\
$\gamma_{1}$ & 0.6817 & 0.7027 & 0.6379 & 0.6390 \\
\hline $\mathrm{WH}_{2}$ & 372.0930 & 271.3287 & 657.3016 & 496.5123 \\
$\gamma_{2}$ & 0.8265 & 0.8211 & 0.8906 & 0.8588 \\
\hline $\mathrm{WH}_{3}$ & 540.9163 & 349.5146 & 806.5601 & 638.9971 \\
$\gamma_{3}$ & 1.0000 & 1.0000 & 1.0000 & 1.0000 \\
\hline
\end{tabular}

Table 5. 3-State Model Productivity Level Estimates

\begin{tabular}{||l|c|c|c|c||}
\hline \multirow{2}{*}{ Prod levels } & \multicolumn{2}{|c|}{ High School Graduates } & \multicolumn{2}{c|}{ College Graduates } \\
\cline { 2 - 5 } & Males & Females & Males & Females \\
\hline$P_{1}$ & 395.7401 & 318.6031 & 605.9314 & 523.0870 \\
& $(5.7457)$ & $(5.5278)$ & $(10.2887)$ & $(10.1004)$ \\
\hline$P_{2}$ & 507.6457 & 355.3006 & 788.8651 & 600.8909 \\
& $(9.5974)$ & $(6.3247)$ & $(15.0659)$ & $(11.0081)$ \\
\hline$P_{3}$ & 774.6683 & 495.3922 & 1020.1706 & 835.6424 \\
& $(22.6114)$ & $(14.2191)$ & $(29.7718)$ & $(26.7376)$ \\
\hline $\mathbf{E P}\left(\gamma_{i}-\gamma_{i-1}\right)$ & 477.6918 & 354.5788 & 697.4669 & 584.3359 \\
\hline
\end{tabular}

Note: Standard errors in parentheses.

Table 6. Averages Predicted by 3-State Model

\begin{tabular}{||l|l|l|l|l||}
\hline \multirow{2}{*}{} & \multicolumn{2}{|l|}{ High School Graduates } & \multicolumn{2}{l|}{ College Graduates } \\
\cline { 2 - 5 } & Males & Females & Males & Females \\
\hline Weekly Wage - Offer Distribution & 287.42 & 220.66 & 436.76 & 363.60 \\
\hline Weekly Wage - Earnings Distribution & 348.64 & 249.04 & 565.05 & 447.25 \\
\hline Job Duration & 98.22 & 112.16 & 182.75 & 134.66 \\
\hline $\begin{array}{l}\text { Non-emp Spell Duration - } \\
\text { unemployed at start }\end{array}$ & 51.91 & 59.20 & 29.97 & 40.92 \\
\hline $\begin{array}{l}\text { Non-emp Spell Duration - } \\
\text { non-participation at start }\end{array}$ & 51.91 & 112.07 & 37.00 & 284.41 \\
\hline
\end{tabular}


Table 7. Thought Experiments on High School Graduates

\begin{tabular}{||l|c|c|c|c||}
\hline & Males & Females & $\begin{array}{c}\text { Females with male } \\
\kappa_{0} \text { and } \kappa_{1}\end{array}$ & Females with $\eta_{1}=0$ \\
\hline$\kappa_{0}$ & 3.5839 & 3.2361 & 3.5839 & 4.0352 \\
\hline$K_{1}$ & 1.7999 & 1.3376 & 1.7999 & 1.6678 \\
\hline$R$ & 133.33 & 122.52 & 115.58 & 136.83 \\
\hline $\begin{array}{l}\text { Offer Distribution } \\
\text { (w) }\end{array}$ & 287.42 & 220.66 & 227.10 & 235.32 \\
\hline Median & 274.91 & 218.67 & 225.12 & 232.71 \\
\hline $25 \%$-tile & 210.90 & 174.61 & 175.59 & 189.21 \\
\hline $\begin{array}{l}\text { Earnings Distribution } \\
\text { E(w) }\end{array}$ & 348.64 & 249.04 & 265.96 & 268.75 \\
\hline
\end{tabular}

Table 8. Thought Experiments on College Graduates

\begin{tabular}{||l|c|c|c|c||}
\hline & Males & Females & $\begin{array}{c}\text { Females with male } \\
\kappa_{0} \text { and } \kappa_{1}\end{array}$ & Females with $\eta_{1}=0$ \\
\hline$\kappa_{0}$ & 14.2628 & 8.0812 & 14.2628 & 9.9418 \\
\hline$\kappa_{1}$ & 2.7737 & 2.2176 & 2.7737 & 2.7282 \\
\hline$R$ & 151.52 & 144.93 & 284.84 & 179.35 \\
\hline $\begin{array}{l}\text { Offer Distribution } \\
\text { E(w) }\end{array}$ & 436.76 & 363.60 & 437.34 & 389.53 \\
\hline median & 424.14 & 360.65 & 427.78 & 384.87 \\
\hline $25 \%$-tile & 303.17 & 264.02 & 364.35 & 293.62 \\
\hline $\begin{array}{l}\text { Earnings Distribution } \\
\text { E(w) }\end{array}$ & 565.05 & 447.25 & 511.76 & 481.89 \\
\hline
\end{tabular}


Appendix A. Data Documentation

Table A.1. Effect of Restrictions on Sample Size

\begin{tabular}{lllll}
\hline \hline & \multicolumn{2}{l}{ High School } & \multicolumn{2}{l}{ College } \\
Restriction & Male & Female & Male & Female \\
\hline Number of white graduates & 1306 & 1468 & 749 & 795 \\
Graduate before 1/1/78 & 1009 & 1058 & 749 & 794 \\
At least one full-time job spell & 939 & 953 & 638 & 632 \\
$\begin{array}{l}\text { Full-time job spell within three years of graduation } \\
\text { date but not starting more than one year before }\end{array}$ & 814 & 822 & 549 & 532 \\
$\begin{array}{l}\text { Valid start and stop dates; no missing data (wage, } \\
\text { hours or reason for leaving) }\end{array}$ & 698 & 722 & 505 & 491 \\
Private Sector & & & & \\
Acceptable wage data (CPS bounds) & 644 & 649 & 420 & 380 \\
Trim top 5\% & 589 & 585 & 388 & 358 \\
\hline \hline
\end{tabular}


Table A.2. 5th and 95th Hourly Wage Bounds From the CPS (Current Dollars)

\begin{tabular}{|c|c|c|c|c|c|c|c|c|c|}
\hline Year & $\begin{array}{l}\text { Min. } \\
\text { wage }\end{array}$ & $\begin{array}{l}\text { High S } \\
\text { Males } \\
\text { 5th } \\
\text { \%-tile }\end{array}$ & $\begin{array}{l}\text { hool- } \\
\text { 95th } \\
\text { \%-tile }\end{array}$ & $\begin{array}{l}\text { High S } \\
\text { Female } \\
\text { 5th } \\
\text { \%-tile }\end{array}$ & $\begin{array}{l}\text { ol - } \\
\text { 95th } \\
\% \text {-tile }\end{array}$ & $\begin{array}{l}\text { 5th \%- } \\
\text { tile }\end{array}$ & $\begin{array}{l}\text { 95th } \\
\% \text {-tile }\end{array}$ & $\begin{array}{l}\text { College } \\
\text { Females } \\
\text { 5th \%- } \\
\text { tile }\end{array}$ & 95th \\
\hline 1979 & 2.90 & 2.90 & 8.50 & 2.50 & 5.60 & 2.90 & 8.00 & 1.90 & 7.00 \\
\hline 1980 & 3.10 & 3.10 & 9.40 & 2.65 & 6.15 & 3.10 & 9.50 & 2.75 & 8.00 \\
\hline 1981 & .3 .35 & 3.35 & 10.30 & 2.85 & 7.00 & 3.35 & 10.50 & 3.20 & 9.50 \\
\hline 1982 & 3.35 & 3.35 & 11.50 & 2.70 & 7.90 & 3.35 & 11.00 & 3.35 & 10.40 \\
\hline 1983 & 3.35 & 3.35 & 12.00 & 3.00 & 8.75 & 3.35 & 13.00 & 3.35 & 11.00 \\
\hline 1984 & 3.35 & 3.35 & 13.00 & 3.00 & 9.00 & 3.35 & 13.50 & 3.35 & 12.00 \\
\hline 1985 & 3.35 & 3.50 & 13.80 & 3.30 & 10.00 & 3.35 & 15.00 & 3.35 & 12.60 \\
\hline 1986 & 3.35 & 3.63 & 14.00 & 3.35 & 10.25 & 3.50 & 15.50 & 3.35 & 13.60 \\
\hline 1987 & 3.35 & 4.00 & 15.00 & 3.35 & 11.00 & 3.65 & 17.50 & 3.50 & 15.00 \\
\hline 1988 & 3.35 & 4.00 & 15.50 & 3.35 & 11.50 & 4.00 & 18.00 & 3.70 & 17.00 \\
\hline 1989 & 3.35 & 4.25 & 16.10 & 3.35 & 12.00 & 4.25 & 19.00 & 4.00 & 19.00 \\
\hline 1990 & 3.80 & 4.50 & 17.00 & 3.75 & 12.50 & 4.25 & 22.00 & 4.25 & 20.00 \\
\hline 1991 & 4.25 & 4.75 & 17.85 & 4.00 & 13.00 & 4.75 . & 24.00 & 4.50 & 22.00 \\
\hline
\end{tabular}

are as follows:

The conditions for a response concerning the time and pay rate for a full-time job to be acceptable

1) If the time rate is coded as hourly, the pay rate must fall within the above bounds given the sex, year and education status.

2) If the time rate is coded as daily, the pay rate must fall within the above bounds multiplied by 8 .

3) If the time rate is coded as weekly, the pay rate must fall within the lower bound times $\mathbf{3 0}$ and the upper bound times 50 .

4) If the time rate is coded as bi-weekly, the pay rate must fall within the bounds in (3) multiplied by 2.

5) If the time rate is coded as monthly, the pay rate must fall within the bounds in (3) multiplied by 4.3.

6) If the time rate is coded as annually, the pay rate must fall within the bounds in (3) multiplied by 52.

7) If the time rate is coded as other or missing, the wage is deemed unacceptable. 


\section{REFERENCES}

Barnes, William F. and Ethel Jones (1974) "Differences in Male and Female Quitting," Journal of Human Resources 9, 439-51.

van den Berg, Gerard and Geert Ridder (1993a) "Estimating an Equilibrium Search Model from Wage Data," in Panel Data and Labour Market Dynamics, H. Bunzel, P. Jensen and N. WestergårdNielsen, eds, North-Holland, 43-56.

(1993b) "An Empirical Equilibrium Search Model of the Labour Market," Free University Amsterdam, mimeo.

Blau, Francine and Lawrence Kahn (1981) "Race and Sex Differences in Quits by Young Workers," Industrial Labor Relations Review 34, 563-77.

Bowlus, Audra J., Kiefer, Nicholas M., and George R. Neumann (1995a) "Estimation of Equilibrium Wage Distributions With Heterogeneity," Journal of Applied Econometrics, forthcoming. (1995b) "Fitting Equilibrium Search Models to Labour Market Data," University of Western Ontario, mimeo, March 1995.

Burdett, Kenneth, Kiefer, Nicholas M., Mortensen, Dale T., and George R. Neumann (1984) "Earnings, Unemployment, and the Allocation of Time Over Time," Review of Economic Studies 51, 559. 578.

Cain, Glen G. (1986) "The Economic Analysis of Labor Market Discrimination: A Survey," in 0. Ashenfelter and R. Layard, eds. Handbook of Labor Economics Volume One, North-Holland, 693785.

Donahue, John J. (1988) "Determinants of Job Turnover of Young Men and Women in the United States," Research in Population Economics 6, 257-301.

Eckstein, Zvi and Kenneth I. Wolpin (1990) "Estimating a Market Equilibrium Search Model from Panel Data on Individuals," Econometrica 58, 783-808.

Flinn, Christopher J. and James J. Heckman (1983) "Are Unemployment and Out of the Labor Force Behaviorally Distinct Labour Force States?" Journal of Labor Economics 1(1), 28-42.

Gönuil, Füsun (1992) "New Evidence on Whether Unemployment and Out of the Labor Force are Distinct States," The Journal of Human Resources 27(2), 329-361.

Hersch, Joni and Patricia Reagan (1990) "Job Match, Tenure and Wages Paid by Firms," Economic Inquiry 28, 488-507.

Applied Economics 26, 205-15.

(1994) "Job Matching and Women's Wage-Tenure Profile," 
Kiefer, Nicholas M. and George R. Neumann (1993) "Wage Dispersion with Homogeneity: The Empirical Equilibrium Search Model," in H. Bunzel, P. Jensen and N. Westergård-Nielsen, eds. Panel Data and Labour Market Dynamics, North-Holland, 57-74.

Lazear, Edward P. and Sherwin Rosen (1990) "Male-Female Wage Differentials in Job Ladders," Journal of Labor Economics 8(1), S106-S123.

Light, Audrey and Mamuelita Ureta (1990) "Gender Differences in Wages and Job Turnover among Continuously Employed Workers," American Economic Review 80, 293-97.

(1992) "Panel Estimates of Male and Female Job Turnover Behavior: Can Female Non-Quitters be Identified?" Journal of Labor Economics 10, 156-81. (1995) "Early Career Work Experience and Gender Wage Differentials," Journal of Labor Economics 13, 121-54.

Meitzen, Mark E. (1986) "Differences in Male and Female Job-quitting Behavior," Journal of Labor Economics 4, 151-67.

Mincer, Jacob and Haim Ofek (1982) "Interrupted Work Careers: Depreciation and Restoration of Human Capital," Journal of Human Resources 17, 3-24.

Mincer, Jacob and Solomon Polachek (1974) "Family Investments in Human Capital: Earnings of Women," Journal of Political Economy 82, S76-S108.

Mortensen, Dale (1990) "Equilibrium Wage Distributions: A Synthesis," in J. Hartog, G. Ridder and J. Theeuwes, eds. Panel Data and Labour Market Studies, North-Holland, 279-296.

Mortensen, Dale and George R. Neumann (1988) "Estimating Structural Models of Unemployment and Job Duration in Dynamic Econometric Modelling," proceeding of the Third International Symposium in Economic Theory and Econometrics, Cambridge University Press.

Ragan, James F. and Sharon P. Smith (1981) "The Impact of Differences in Turnover Rates on Male/Female Pay Differentials," Journal of Human Resources 26, 343-65.

Royalty, Anne Beeson (1993a) "Does Job Matching Differ by Sex?" Yale University Economic Growth Center Discussion Paper \#689.

(1993b) "A Comparison of the Effects of Matching and Search on the Wages of Men and Women," Yale University Economic Growth Center Discussion Paper \#690.

Sandell, Steven and David Shapiro (1980) "Work Expectations, Human Capital Accumulation, and the Wages of Women," Journal of Human Resources 15, 335-53.

Sicherman, Nachum (1993) "Gender Differences in Departures from a Large Firm," NBER Working Paper \#4279. 
Swaim, Paul and Michael Podgursky (1994) "Female Labor Supply Following Displacement: A SplitPopulation Model of Labor Force Participation and Job Search," Journal of Labor Economics 12(4), 640-656.

Viscusi, W. Kip (1980) "Sex Differences in Worker Quitting," Journal of Human Resources 62, 388-98. 